\section{Garden Club of America}

14 East 60th Street 3rd Floor, New York, NY 10022, United States of America.

Tel: $\quad$ (1) 2127538287

Email: judygow@comcast.net

Website: www.gcamerica.org

Contact: Judy Gow, Vice Chairman

The Garden Club of America stimulates the knowledge and love of gardening, shares the advantages of association by means of educational meetings, conferences, correspondence and publications, and restores, improves and protects the quality of the environment through educational programmes and action in the fields of conservation and civic improvement.

\section{The Anne S. Chatham Fellowship}

Purpose: To protect and preserve knowledge about the medicinal use of plants and thus prevent the disappearance of plants with therapeutic potential

Eligibility: Open to candidates who are currently enroled in $\mathrm{PhD}$ programmes or have obtained a $\mathrm{PhD}$ or a graduate degree

Level of Study: Doctorate, Postdoctorate

Type: Fellowship

Value: US $\$ 4,500$

Frequency: Annual

Country of Study: Any country

Application Procedure: Applicants must submit an application letter, an abstract, a research proposal and a curriculum vitae

Closing Date: 31 January

Contributor: Garden Club of America
Additional Information: Contact Wendy Applequist for more information www.missouribotanicalgarden.org/plantscience/plant-science/william-1-brown-center/wlbc-resources/ wlbc-awards/anne-s.-chatham-fellowship.aspx

\section{For further information contact:}

Missouri Botanical Garden, PO Box 299, St Louis, MO 63166, United States of America.

Tel: (1) 3145779503

Email: wendy.applequist@mobot.org

\section{Gates Cambridge Trust}

PO Box 252, Cambridge CB2 1TZ, United Kingdom.

Tel:

$$
\text { (44) } 1223338467
$$

Email: info@gates.scholarships.cam.ac.uk

Website: www.gates.scholarships.cam.ac.uk

Contact: Board of Graduate Studies

\section{Gates Cambridge Scholarship}

Purpose: The Gates Cambridge Scholarship programme was established in October 2000 by a donation of US $\$ 210 \mathrm{~m}$ from the Bill and Melinda Gates Foundation to the University of Cambridge; this is the largest ever single donation to a United Kingdom university. Scholarships are awarded to outstanding applicants from countries outside the United Kingdom to pursue a full-time postgraduate degree in any subject available at the University of Cambridge. The selection criteria are: 1. outstanding intellectual ability. 2. leadership potential. 3. a commitment to improving the lives of others. 4. a good fit between the applicant's qualifications and aspirations and the postgraduate programme at Cambridge for which they are 
applying. While at Cambridge, Scholars pursue the full range of subjects available at the University and are spread across its departments and Colleges. The aim of the Gates Cambridge programme is to build a global network of future leaders committed to improving the lives of others

Eligibility: You can apply for a Gates Cambridge Scholarship if you are: 1. a citizen of any country outside the United Kingdom. 2. applying to pursue one of the following fulltime residential courses of study at the University of Cambridge. PhD (three year research-only degree). MSc or MLitt (two year research-only degree). One year postgraduate course (e.g. MPhil, LLM, MASt, Diploma, MBA etc.). There is no age restriction for applications

Level of Study: Doctorate, MBA, Postgraduate, Postgraduate (MSc)

Type: Scholarship

Value: Tuition fees and maintenance allowance of $£ 17,500$

Length of Study: 12 months \& PhD scholars the award is for up to 4 years

Frequency: Annual

Study Establishment: University of Cambridge

Country of Study: United Kingdom

Application Procedure: Complete relevant funding section of the University of Cambridge application form

Closing Date: 7 January

Funding: Foundation

Contributor: Bill and Melinda Gates Foundation

No. of awards given last year: 90

Additional Information: Candidates must apply for a place at the University of Cambridge and for funding at the same time, using the University of Cambridge application portal there is no separate Gates Cambridge application form except for MBA and MFin applicants who should consult the Cambridge Judge Business School website www.gatescambridge. org/apply-overview

\section{For further information contact:}

The Warehouse, Ground Floor, 33 Bridge Street, Cambridge CB2 1UW, United Kingdom.

Fax: (44) 1223577004

Email: info@gatescambridge.org

\section{General Social Care Council}

Goldings House, 2 Hay's Lane, London SE1 2HB, United Kingdom.

Tel: $\quad$ (44) 2073975100

Email: info@bursaries.gscc.org.uk
Website: www.gscc.org.uk

Contact: Administrative Officer

The General Social Care Council is the first ever regulatory body for the social care profession in United Kingdom. It was set up to establish codes of conduct and practice for social care workers, a register of practicing professionals and to regulate and support social work, education and training. It takes forward some of the work of the Central Council for Education and Training in Social Work, which closed on September 28, 2001. Similar councils exist for Northern Ireland, Scotland and Wales.

\section{Social Work Bursary}

Purpose: To support those seeking the qualifications required for social work

Eligibility: Open to graduates, who have ordinarily been resident in United Kingdom studying on an approved fulltime postgraduate course. Amongst other eligibility criteria, students must also meet certain residency criteria. Please refer to the application packs for full eligibility criterion

Level of Study: Postgraduate

Type: Bursary

Value: Non-income-assessed grant of $£ 2,500-2,900$ and a contribution towards practice learning opportunity related expenses and tuition fees. It also includes a income-assessed maitenance grant and allowances to assist cost of living

Length of Study: 2 years

Frequency: Annual

Study Establishment: Accredited higher education institutions running a social work course approved by the General Social Care Council, the Scottish Social Services Council, the Care Council for Wales or the Northern Ireland Social Care Council

Country of Study: United Kingdom

Application Procedure: Application guide is available on the following linkwww.nhsbsa.nhs.uk/sites/default/files/ 2019-07/Your\%20guide\%20to\%20Social\%20Work\%20Bur saries $\% 202019-20 \% 20 \% 28 \mathrm{~V} 2 \% 29 \% 2007 \% 202019$.pdf

No. of awards offered: 2300

Closing Date: 1 February

Funding: Government

Contributor: The Department of Health

No. of awards given last year: 2100

No. of applicants last year: 2300

Additional Information: The bursary is a year-to-year funding arrangement. The bursary terms and conditions (including rates) may change from year-to-year www.gov. uk/social-work-bursaries 


\section{For further information contact:}

NHS Business Services Authority, Sandyford House, Archbold Terrace, Newcastle Upon Tyne NE2 1DB, United Kingdom.

Tel: (44) 3003301343

Email: swb@ppa.nhs.uk

\section{GeneTex}

\section{GeneTex Scholarship Program}

Purpose: GeneTex believes in accelerating scientific advancement and the notion that the genesis of future discoveries begins with the support of young scientists today. The GeneTex Scholarship Program is intended for students that have declared a STEM major or are enrolled in a STEM graduate program

Eligibility: 1. Student in good standing and enrolled at an accredited college or university. 2. Declared STEM major. 3. Open to international students. 4. All accredited Universities are eligible.

Level of Study: Postgraduate

Type: Programme grant

Value: US $\$ 2,000$

Frequency: Annual

Country of Study: Any country

Application Procedure: See the website. www.genetex.com/ Article/Company?param1 $=$ Scholarship

Closing Date: 16 July

Funding: Private

Additional Information: www.genetex.com/Article/Com pany/Index/Scholarship

\section{For further information contact:}

2456 Alton Parkway, Irvine, CA 92606, United States of America.

Tel: $\quad$ (1) 9495531900

Email: scholarship@genetex.com

\section{Geological Society of America (GSA)}

3300 Penrose Place, PO Box 9140, Boulder, CO 80301-1806, United States of America.

Tel: $\quad$ (1) 3033571000

Email: awards@geosociety.org
Website: www.geosociety.org

Contact: Ms Program Manager, Grants, Awards and Recognition

Established in 1888, the GSA is a non-profit organization dedicated to the advancement of the science of geology. GSA membership is for the generalist and the specialist in the field of geology and offers something for everyone

\section{J. Hoover Mackin Award}

Purpose: The award is given annually to an outstanding $\mathrm{PhD}$ student, on the basis of a research proposal submitted to the GSA student research grant program

Eligibility: 1. Eligibility is restricted to GSA members. 2. Applicants must be currently enrolled in a North American or Central American university or college in an earth science graduate degree program (with a geologic component). 3 . The research focus can be any subject matter within the geological sciences, such as paleontology, karst, geochemistry, stratigraphy, geoscience education, petroleum geology, and more. 4. Students may receive a total of two GSA graduate student grants in their entire academic career, regardless of what program currently enrolled in.

Level of Study: Postgraduate

Type: Award

Country of Study: Any country

Application Procedure: The Application Procedures are Available at: www.geosociety.org/gradgrants

Closing Date: 1 February

Additional Information: community.geosociety.org/ qggdivision/awards/mackin

\section{For further information contact:}

Geological Society of America, P.O. Box 9140, Boulder, CO 80301-9140, United States of America.

Tel: $\quad$ (1) 3033571025

Email: researchgrants@geosociety.org

\section{Marie Morisawa Award}

Purpose: To support promising female MS and $\mathrm{PhD}$ graduate students pursuing a career in geomorphology

Eligibility: Female scientists in geomorphology currently enroled in a Masters or $\mathrm{PhD}$ program are encouraged to apply Level of Study: Graduate, Research

Type: Fellowship

Value: US $\$ 1,000$ 
Frequency: Annual

Country of Study: Any country

Application Procedure: The Application Procedures are Available at: www.geosociety.org/gradgrants

Closing Date: 1 February

No. of awards given last year: 1

Additional Information: Please check atrock.geosociety. org/qgg/M-H\%20As.html community.geosociety.org/

qggdivision/awards/morisawa

\section{For further information contact:}

Geological Society of America, P.O. Box 9140, Boulder, CO 80301-9140, United States of America.

Tel: $\quad$ (1) 3033571025

Email: researchgrants@geosociety.org

\section{George A and Eliza Gardner Howard Foundation}

Brown University, Box 1867, 42 Charlesfield Street, Providence, RI 02912, United States of America.

Tel: $\quad$ (1) 4018632640

Email: howard foundation@brown.edu

Website: www.brown.edu/divisions/graduate_school/ howard

Contact: Ms Susan M Clifford, Co-ordinator

The George A and Eliza Gardner Howard Foundation was established in 1952 by Nicea Howard in memory of her grandparents. Although Miss Howard had a special interest in the arts, her stated purpose was to aid the personal development of promising individuals at the crucial middle stages of their careers.

\section{George A. and Eliza Gardner Howard Foundation}

Subject: Photography and Film Studies

Purpose: Awards a limited number of fellowships each year for independent projects in selected fields, targeting its support specifically to early mid-career individuals, those who have achieved recognition for at least one major project. Our support is particularly intended to augment paid sabbatical leaves. In the case of independent artists or scholars, or those without paid leaves, we would expect that a Howard Fellowship would enable them to devote a substantial block of time to the proposed project. A total of eight fellowships of US\$35,000 will be awarded in April 2020 for 2020-2021 in the fields of: Fiction, Poetry, and Playwriting and Theater Studies

Eligibility: In order to be eligible to apply for a Howard Fellowship, candidates should be able to answer "yes" to each of the following questions. If "no" is the correct answer to any of them, they are asked to explain on the application form what special circumstances might make them eligible anyway, given the requirements for a Howard Fellowship. Can your current professional status appropriately be viewed as "early mid-career" as understood by the Howard Foundation? Appropriate candidates for a Howard Fellowship should have completed their formal studies within the past five to fifteen years of the application date and should also have successfully completed at least one major project beyond degree requirements that would be sufficient for the awarding of tenure at a research institution or for achieving comparable peer recognition, e.g., through publication or exhibition. Candidates who are already nationally and internationally recognized leaders in their fields as reflected by their promotion to full professor or by comparable recognition in their fields of endeavor are not normally eligible for a Howard Fellowship. Would a Howard Fellowship provide you with time off from other responsibilities to work on your proposed project? Our support is particularly intended to augment paid sabbatical leaves. In the case of independent artists or scholars, or those without paid leaves, we would expect that a Howard Fellowship would enable them to devote a substantial block of time to the proposed project. Are you, regardless of your citizenship, currently living and working in the United States or United States of America Territories?; Does your proposed project fall within one of the fields established for this year's round of applications? Given the limits of our resources, we must adhere strictly to the fields announced each year for project proposals

Level of Study: Doctorate, Postdoctorate, Postgraduate, Postgraduate (MSc)

Type: Fellowships

Value: US\$35,000

Frequency: Annual

Country of Study: United States of America

Application Procedure: Applications accepted through https://howardfoundation.smapply.org/

No. of awards offered: 9

Closing Date: 1 November

Funding: Foundation

No. of awards given last year: 9

No. of applicants last year: $100-300$

Additional Information: www.brown.edu/howardfoundation/ 


\section{For further information contact:}

Brown University, Box 1867, 42 Charlesfield Street, Providence, RI 02912, United States of America.

Tel: $\quad$ (1) 4018632429

Fax: (1) 4018631339

Email: Howard_Foundation@brown.edu

\section{Gerber Foundation}

\section{Novice Research Awards}

Subjects: Pediatric research

Purpose: To provide funding for novice researchers studying pediatrics and related subjects

Eligibility: Organizations recognized as tax-exempt under Internal Revenue Code 501(c)(3) are eligible to apply for Foundation grants. Public governmental institutions such as universities are included in this definition. Organizations must also be determined not to be private foundations under Internal Revenue Code 509. No grants are made to individuals. With few exceptions, only organizations with principal operations in the United States and its territories are eligible for funding. Within the United States, there is no geographic limitation to the Foundation' grantmaking.

Type: Grant

Value: Max. US $\$ 20,000$ in total

Frequency: Twice a year

Country of Study: Any country

Application Procedure: Apply online

Closing Date: 15 November

Additional Information: www.gerberfoundation.org/howto-apply/

\section{German Academic Exchange Service (DAAD)}

\section{Dissertation Research Scholarship}

Subjects: All

Purpose: Study scholarships are awarded to highly qualified graduate students to study in Germany or complete a post graduate or Master's degree course and obtain a degree at a German university or institution

Eligibility: Research grants are awarded primarily to highly qualified doctoral candidates as well as Master's degree holders and post-doc researcher for research or a course of study and training at universities or other institutes in Germany.

Type: Research grant

Country of Study: Germany

Closing Date: 15 Novermber

Additional Information: Applicants should possess knowledge of the German language commensurate with the demands of their research project. The grant consists of a monthly maintenance allowance, international travel subsidy and health insurance www.daad.org

\section{German Historical Institute}

1607 New Hampshire Avenue North West, Washington DC 20009-2562, United States of America.

Tel: $\quad$ (1) 2023873355

Email: fellowships@ghi-dc.org

Website: www.ghi-dc.org

Contact: Bryan Hart

The German Historical Institute is an independent research institute dedicated to the promotion of historical research in the Federal Republic of Germany and the United States of America. The Institute supports and advises German and American historians and encourages co-operation between them. It is part of the foundation Deutsche Geisteswissenschaftliche Institute im Ausland (DGIA).

\section{German Historical Institute Collaborative Research Program for Postdoctoral Scholars}

Purpose: To support a research programme for postdoctoral scholars on the topic of continuity, change and globalization in postwar Germany and the United States of America

Eligibility: Open to German and United States of America postdoctoral students. Applications from women and minorities are especially encouraged

Level of Study: Postdoctorate

Type: Fellowship

Value: US $\$ 20,000-40,000$, dependent on length of study

Length of Study: 6 months-1 year

Frequency: Dependent on funds available

Country of Study: United States of America

Application Procedure: Applicants must refer to the website for details

Funding: Government

Contributor: The National Endowment for Humanities

No. of awards given last year: 1 


\section{For further information contact:}

Email: westermann@ghi-dc.org

\section{GHI Fellowships at the Horner Library}

Purpose: The fellowship will be awarded to $\mathrm{PhD}$ and M.A. students and advanced scholars without restrictions in research fields or geographical provenance.

Level of Study: Doctorate, Masters Degree

Type: Fellowship

Value: travel subsidy and an allowance of US $\$ 1,000$ to US $\$ 3,500$ depending on the length of the stay

Frequency: Annual

Country of Study: Any country

Application Procedure: To apply please send the following materials using the online application form or (as a single pdf). They should include: 1 . a project description of no more than 2,000 words, 3 . curriculum vitae, 2.copies of academic degrees, 3. and one letter of reference (sent seperately to fellowships@ghi-dc.org). Applicants may write in either English or German; we recommend that they use the language in which they are most proficient. Applicants will be notified about the outcome approximately two months after the deadline.

Closing Date: 1 March

For further information contact:

Email: hart@ghi-dc.org

\section{Summer Seminar in Germany}

Purpose: To introduce students to German handwriting of previous centuries by exposing them to a variety of German archives, familiarizing them with major research topics in German culture and history and encouraging the exchange of ideas among the next generation of United States of America scholars

Eligibility: Open to United States of America doctoral students. Applications from women and minorities are especially encouraged

Level of Study: Doctorate

Type: Scholarship

Value: All transportation and accommodations

Length of Study: 2 weeks

Frequency: Annual

Country of Study: Germany

Application Procedure: Applicants must refer to the website for details

Closing Date: 31 January

Funding: Government

No. of awards given last year: Varies

Additional Information: Questions may be directed to Elisabeth Engel at engel@ghi-dc.org

\section{For further information contact:}

Email: laurence.mcfalls@umontreal.ca

Transatlantic Doctoral Seminar in German History

Purpose: To bring together young scholars from Germany and the United States of America who are nearing completion of their doctoral degrees. It provides an opportunity to debate doctoral projects in a transatlantic setting

Eligibility: Open to doctoral students in German history at North American and European Universities. Applications from women and minorities are especially encouraged

Level of Study: Doctorate

Type: Scholarship

Value: Travel and accommodation

Length of Study: 4 days

Frequency: Annual

Country of Study: Germany

Application Procedure: Applicants must refer to the website for details

No. of awards offered: Varies

Closing Date: 15 January

Funding: Government

Contributor: German Historical Institute Washington Georgetown University

No. of awards given last year: 16

No. of applicants last year: Varies

Additional Information: Questions may be directed to Dr Richard F. Wetzell at r.wetzell@ghi-dc.org

\section{For further information contact:}

Email: mlist@ghi-dc.org

\section{German Marshall Fund of the United States (GMF)}

1744 R Street NW, Washington DC 20009, United States of America.

Tel:

Email:

Website:

Contact: Lea Rosenbohm, Administrative Assistant 
The German Marshall Fund (GMF) of the United States is an American institution that stimulates the exchange of ideas and promotes co-operation between the United States and Europe in the spirit of the post war Marshall Plan. GMF was created in 1972 by a gift from Germany as a permanent memorial to Marshall Plan Aid.

\section{German Marshall Fund Journalism Program}

Purpose: To contribute to better reporting on transatlantic issues by both American and European journalist

Eligibility: Open to American and European journalists who have an outstanding record in reporting on foreign affairs

Level of Study: Postdoctorate, Professional development

Type: Fellowship

Value: US\$2,000-25,000 and funds for travel

Frequency: Annual

Application Procedure: Applicants including a description of the proposed project, current curriculum vitae and samples of previous work must be sent

Funding: Foundation

Contributor: The German Marshall Fund

For further information contact:

Email: usoyez@gmfus.org

\section{German Studies Association}

Kalamazoo College, 1200 Academy Street, Kalamazoo, MI 49006-3295, United States of America.

Tel: $\quad$ (1) 2692677585

Email:_director@thegsa.org

Website: www.thegsa.org

Contact: David E. Barclay, Executive Director

The German Studies Association (GSA) is a non-profit educational organization that promotes the research and study of Germany, Austria and Switzerland. The GSA Endowment Fund provides financial support to Association projects, the annual conference, and general operations.

\section{Berlin Program Fellowship}

Purpose: To support doctoral dissertation research as well as postdoctoral research leading to the completion of a monograph
Eligibility: Applicants for a dissertation fellowship must be full-time graduate students who have completed all coursework required for the $\mathrm{PhD}$ and must have achieved ABD status by the time the proposed research stay in Berlin begins. Also eligible are United States of America and Canadian $\mathrm{PhDs}$ who have received their doctorates within the past 2 calendar years

Level of Study: Doctorate, Postdoctorate

Type: Fellowship

Value: $€ 1,100$ per month for dissertation fellows, $€ 1,400$ per month for postdoctoral fellows

Length of Study: 10-12 months

Frequency: Annual

Study Establishment: Freie Universität Berlin

Country of Study: Germany

Application Procedure: Applicants must submit a single application packet consisting of completed application forms, a proposal, three letters of reference, language evaluation(s) and graduate school transcripts. Proposals should be no longer than 2,500 words or 10 pages, followed by a one- or two-page bibliography or bibliographic essay

Closing Date: 17 March

Contributor: Halle Foundation and the National Endowment for the Humanities

\section{For further information contact:}

Berlin Program for Advanced German and European Studies, Freie Universität Berlin, Garystrasse 45, D-14195 Berlin, Germany.

Tel: (49) 3083856671

Fax: (49) 3083856672

Email: bprogram@zedat.fu-berlin.de

\section{Getty Foundation}

1200 Getty Center Drive, Suite 800, Los Angeles, CA 900491685, United States of America.

Tel:

(1) 3104407320

Email:_researchgrants@getty.edu

Website: www.getty.edu/grants

Contact: Grants Administration

The J Paul Getty Trust is a privately operating foundation dedicated to the visual arts and the humanities. The Getty supports a wide range of projects that promote research in fields related to the history of art, the advancement of the understanding of art and the conservation of cultural heritage. 


\section{Postdoctoral Fellowships in Conservation Science}

Purpose: To provide recent $\mathrm{PhDs}$ in chemistry or the physical sciences with experience in the GCI's Museum Research Laboratory

Eligibility: Open to scientists of all nationalities who are interested in pursuing a career in conservation science and have received a $\mathrm{PhD}$ in chemistry/physical science and have excellent written and oral communication skills

Level of Study: Research

Type: Fellowship

Value: US\$29,300 per year

Length of Study: 2 years

Country of Study: Any country

Application Procedure: Applicants must complete and submit an online application which includes completing an online information form, and uploading a Statement of Interest in Conservation Science, Doctoral Dissertation Abstract, Curriculum Vitae, Writing Sample, and Degree Confirmation Letter. Applicants are also required to submit two confidential letters of recommendation in support of the their application Closing Date: November

Additional Information: The successful candidate will have a record of scientific accomplishment combined with a strong interest in the visual arts www.getty.edu/conservation/publi cations_resources/newsletters/33_2/gcinews12.html

\section{For further information contact:}

Attn: Postdoctoral Fellowship in Conservation Science, The Getty Foundation, 1200 Getty Center Drive, Suite 800, Los Angeles, CA 90049, United States of America.

Tel: (1) 3104407374

Fax: (1) 3104407703 (inquiries only)

\section{Ghent University}

Ghent University, Campus Ufo, Rectorate, SintPietersnieuwstraat 25, B-9000 Ghent, Belgium.

Tel: (32) 93310101

Email:_info@ugent.be

Website: www.ugent.be/en/

The Government of Flanders awards scholarships to academically outstanding students for master programmes in Flanders and Brussels.

\section{Master Mind Scholarships}

Purpose: The Flemish Ministry of Education awards scholarships to outstanding students for Master programmes in Flanders and Brussels. The programme aims to promote Flanders and Brussels as a top study destination

Eligibility: 1. The applicant applies to take up a Master degree programme at a higher education institution in Flanders (hereafter 'Flemish host institution'). 2. The applicant should have a high standard of academic performance and/or potential. The student has a Grade Point Average of 3.5 out of 4.0 and has a good knowledge of the English language. 3 . The student has to be accepted by the Host institution to be able to receive the scholarship. Even if the Host institution's decision to accept the student is taken after the selection of the Master Mind Scholarships programme, this criterion applies. 4. All nationalities can apply. The previous degree obtained should be from a higher education institution located outside Flanders. 5. Students who are already enrolled in a Flemish higher education institution cannot apply. See the full eligibility criteria at the 2020-2021 Master Mind Scholarship Guidelines (link found below)

Level of Study: Masters Degree

Type: Scholarships

Value: Maximum scholarship of $€ 8,200$ per academic year

Frequency: Annual

Country of Study: Belgium

Application Procedure: Application procedure fully furnished at www.ugent.be/prospect/en/administration/appli cation/application-degree

No. of awards offered: 30

Closing Date: 1 March

Additional Information: www.ugent.be/en/research/ funding/devcoop/grants-scholarships/master-mind

\section{Gilchrist Educational Trust (GET)}

43 Fern Road, Storrington, Pulborough, West Sussex RH20 4LW, United Kingdom.

Tel: (44) 1903746723

Email:_gilchrist.et@blueyonder.co.uk Website: www.gilchristgrants.org.uk Contact: Mrs J V Considine, Secretary

Gilchrist Educational Trust awards grants to: individuals who face unexpected financial difficulties, which may prevent completion of a degree or higher education course; 
organizations if it seems likely that a project for which funds to sought will fill an educational gap of an academic nature or make more widely available for a particular aspect of academic education or learning; British expeditions proposing to carry out research of a scientific nature abroad.

\section{Gilchrist Fieldwork Award}

Purpose: To fund a period of fieldwork by established scientists or academics

Eligibility: Open to teams wishing to undertake a field season of over 6 weeks in relation to one or more scientific objectives. Teams should consist of not more than 10 members, most of whom should be British and holding established positions in research departments at universities or similar establishments. The proposed research must be original and challenging, achievable within the timetable and preferably of benefit to the host country or region

Level of Study: Research

Type: Grant

Value: $£ 15,000$

Length of Study: At least 6 weeks

Frequency: Every 2 years

Country of Study: Any country

Application Procedure: Send proposal to Secretary

Closing Date: 22 February

Funding: Private

Additional Information: The award is competitive www.rgs. org/in-the-field/in-the-field-grants/research-grants/gilchrist-

fieldwork-award/

\section{For further information contact:}

RGS, 1 Kensington Gore, South Kensington, London SW7 2AR, United Kingdom.

Email: grants@rgs.org

\section{Glasgow Caledonian University}

Cowcaddens Road, Glasgow G4 0BA, Scotland, United Kingdom.

Tel: $\quad$ (44) 1413313000

Contact: Ms Irene Urquhart, MBA Admissions Officer

\section{Glasgow School for Business and Society Postgraduate EU scholarships for MSc International Fashion Marketing}

Purpose: This scholarship scheme is for Postgraduate EU students studying MSc International Fashion Marketing as a new student in academic year 2021-22 who are classified as international students for fees purposes.

Eligibility: 1. These scholarships are restricted to EU applicants who are classified as international students for fees purposes. 2. Applicants must be ordinarily resident in an EU country. 3. Applicants must be entirely self-funded. 4. Applicants must be starting their first year of study on an postgraduate degree course at GCU in September 2021 5. Only one scholarship award can be made per student and the award will not be carried over if you defer studies to another academic year 6. Successful applicants should be available for promotional activities.

Level of Study: Postgraduate

Type: Scholarship

Value: $£ 7,500$

Frequency: Annual

Country of Study: Any country

Application Procedure: Apply online

Closing Date: 1 August

\section{Glasgow School for Business and Society Scholarship}

Purpose: Glasgow School for Business and Society (GSBS) are delighted to introduce new partially funded scholarships. For a wide range of our postgraduate full-time degrees we can offer support with the cost of tuition fees

Eligibility: You must meet the following criteria to be eligible to apply for the scholarship; 1. A permanent resident of Scotland for at least 3 years 2. An EU national or a student from England, Northern Ireland, Wales residing in your own country for 3 years prior to the start of the programme. The partial cost of tuition fees will be covered for eligible students who are successful in gaining an award on the specified programme for one academic year only. Funding is not available for part-time or distance learning versions of these programmes. Awards are non-transferable.

Level of Study: Postgraduate

Type: Scholarship

Value: $£ 3,000$ towards tuition fees.

Frequency: Annual

Country of Study: Any country

Application Procedure: Apply online

Closing Date: 7 January 


\section{Master of Public Health Scholarship}

Purpose: The scholarship associated with this programme offers full-time International students funding towards their tuition fees for the Masters

Eligibility: Any International fee paying student who has applied for the full time Master of Public Health programme at GCU Glasgow Campus

Length of Study: $£ 4,500$

Country of Study: Any country

Application Procedure: Apply online

Closing Date: 15 November

Additional Information: Scholarships will not be deferred to another academic session.

\section{For further information contact:}

Tel: $\quad$ (44) 1413318770

Email: scholarships@gcu.ac.uk

\section{Postgraduate Ambassador Studentship}

Purpose: Glasgow Caledonian is the University for the Common Good. Our mission is to make a positive difference to the communities we serve and this is at the heart of all we do, especially in our social innovation teaching and research.

Eligibility: 1. Must hold an offer of study with GCU before applying or the application will be rejected. 2. You must be able to cover your living costs in line with the UKVI requirements when applying for a Visa. 3. All awards are non-transferable to any other programme or academic session if you are awarded the scholarship. 4. Only applicants on a Full Time Taught Postgraduate Masters course are eligible to apply. 5. No late applications will be accepted. 6. Video Link must be submitted or application will be automatically be rejected.

Level of Study: Postgraduate

Type: Scholarship

Value: Full tuition fee Scholarship up to $£ 15,000$

Country of Study: Any country

Closing Date: 1 June

\section{For further information contact:}

Email: scholarships@gcu.ac.uk

\section{Scotland's Saltire Scholarships}

Purpose: These scholarships are supported and funded by the Scottish Government in partnership with Glasgow Caledonian University
Eligibility: Further information on the eligibility criteria and application process for the Scotland's Saltire Scholarships Scheme is available on the Study in Scotland website.

Level of Study: Doctorate

Value: $£ 8,000$ Tuition fee

Length of Study: one academic year

Frequency: Annual

Country of Study: Any country

Closing Date: 28 May

Funding: Private

\section{For further information contact:}

Email: scholarships@gcu.ac.uk

\section{ScottishPower Masters Scholarships}

Purpose: ScottishPower will provide scholarships for the academic year for postgraduate studies at universities in the United Kingdom

Eligibility: Students who are looking to study the following areas of knowledge: 1. Electrical/Mechanical/Civil Engineering. 2. Renewable/Sustainable Energy. 3. Onshore/Offshore Renewable Engineering. 4. Environmental Sciences /Climate Change. 5. Global Energy Management

Level of Study: Postgraduate

Type: Scholarship

Value: $£ 1,200$ per month

Frequency: Annual

Country of Study: Any country

Application Procedure: ScottishPower are looking for each scholar to: 1. Promote career opportunities available within the company. 2. Act as a STEM ambassador for the industry. 3. Introduce future scholarship applicants to the scheme

Closing Date: 29 March

Funding: Private

Additional Information: Kindly access the below link for processing the application.www.iberdrola.com/people-talent/ international-scholarships-master-iberdrola/apply-scholarshipsaccess www.scottishpower.com/pages/scottishpower_mas ters_scholarships.aspx

\section{For further information contact:}

Glasgow Caledonian University, Cowcaddens Road, Glasgow G4 0BA, Scotland, United Kingdom.

Email: ukroenquiries@gcu.ac.uk 


\section{Goethe-Institut}

Kundenmanagement, Goethestrasse 20, D-80336 München, Germany.

$\begin{array}{ll}\text { Tel: } & \text { (49) } 8915921200 \\ \text { Email: } & \text { deutsch@goethe.de } \\ \text { Contact: } & \text { Goethe-Institut }\end{array}$

The Goethe-Institut is a non-profit German cultural association operational worldwide with 159 institutes, promoting the study of the German language abroad and encouraging international cultural exchange and relations.

\section{Goethe-Institut Postdoctoral Fellowship for International Students}

Purpose: The aim of the fellowship is to support promising and exceptional scholar for one academic year and shall concentrate on the research for a comprehensive exhibition project on the global art historical developments of the Postcolonial era covering the period 1955-1980

Eligibility: International applicants are eligible to apply for the fellowship. Applicants must have a doctorate degree in art history, museum studies or related fields. Applicants must be fluent in English

Type: Postdoctoral fellowship

Value: An overall remuneration package of $€ 30.000$ for the entire year. This includes any health care and tax payments. Accommodation is the responsibility of the successful candidate. Haus der Kunst will provide supplementary support to the scholar for accommodation in the amount of $€ 300$ per month. Haus der Kunst will support the fellow in organizing administrational paperwork such as limited residency, work permit, etc. Fellow will be provided with work area and full access to the infrastructure of Haus der Kunst and facilities in Munich

Frequency: Annual

Study Establishment: Fellowship is awarded for scholars whose research focuses on global perspectives on modern and contemporary art in the second half of the 20th century and the 21 st century

Country of Study: Any country

Application Procedure: Interested scholars are invited to send their application via email. The application should be in English and include a Curriculum Vitae, bibliography, reference letters and a cover letter explaining the motivation for the application

Closing Date: 14 January

\section{For further information contact:}

Email: kredler@hausderkunst.de

\section{Google Sydney}

Google Headquarters, Google Inc., 1600 Amphitheatre Parkway, Mountain View, CA 94043, United States of America.

Tel: $\quad$ (1) 6502530000

Website: www.google.com

Google is a public and profitable company focused on search services. Google operates web sites at many international domains. Google is widely recognized as the "world's best search engine" because it is fast, accurate and easy to use. The company also serves corporate clients, including advertisers, content publishers and site managers with cost-effective advertising and a wide range of revenue generating search services. Google's breakthrough technology and continued innovation serve the company's mission of "organizing the world's information and making it universally accessible and useful".

\section{Lionel Murphy Endowment Postgraduate Scholarship}

Purpose: A number of Australian and overseas postgraduate scholarships are awarded annually by the Lionel Murphy Foundation Endowment. These scholarships are known as the Lionel Murphy Endowment Postgraduate Scholarship. The number of scholarships awarded each year, and the method of payment, is recommended by the Advisory Committee.

Eligibility: This scholarship is applicable for candidates having the preference to study in any of the following areas. 1. The law and the legal system in a social context and their practical application; 2 . Science and/or the law as a means of attaining social justice and human rights and as vehicles for change; 3 . International law as a developing force for peace and as a means of achieving the rule of law in all nations. 4. Science as a tool for social benefit, particularly in meeting the needs of those most disadvantaged within society 5 . Other disciplines, where the proposed nature and area of study are likely to promote the goals of social justice and benefit for the disadvantaged

Level of Study: Postgraduate

Type: Scholarship

Value: AU\$40,000 each per annum 
Length of Study: 1 year

Frequency: Annual

Country of Study: Australia

Application Procedure: Check the website online. lionelmurphy.law.anu.edu.au/postgraduate-scholarship

Closing Date: 30 November

Funding: Private

\section{For further information contact:}

Lionel Murphy Foundation Endowment, c/- Secretariat Coordinator, ANU College of Law, Australian National University, Canberra, ACT 2601, Australia.

Email: lionelmurphy.law@anu.edu.au

\section{Government of the Punjab}

\section{The Punjab Educational Endowment Fund}

Eligibility: 1. Valid $\mathrm{PhD}$ admission offer from one of the Top 50 (Subject Wise) Universities of the World (QS ranking) in preferred subject areas. 2. Not less than 60\% marks throughout the academic career. 3 . Declared monthly family income (including self, spouse and parents) is equal to or less than PKR. 20,000/. 4. Maximum age of 35 years at the time of submission of application. 5. Not availed any foreign scholarship in the past. 6. Must take up the scholarship in the year for which it is offered and the scholarship shall not be deferred to the next year. 7. All Pakistani nationals, both males and females are eligible to apply

Level of Study: Postgraduate

Type: Award

Frequency: Annual

Country of Study: Any country

Closing Date: 22 April

Funding: International office

Additional Information: www.peef.org.pk/update.html

\section{Graduate Fellowships for Science, Technology, Engineering, and Mathematics Diversity}

\section{Graduate Fellowships for Science, Technology, Engineering, and Mathematics Diversity}

Subjects: Astronomy, Chemistry, Computer Science, Geology, Materials Science, Mathematical Sciences, Physics, and their subdisciplines, and related engineering fields: Chemical, Computer, Electrical, Environmental, Mechanical.

Purpose: GFSD's goal is to increase the number of American citizens with graduate degrees in STEM fields, emphasizing recruitment of a diverse applicant pool.

Eligibility: Any qualified U.S. citizen who has the ability to pursue graduate work at an GFSD univresity associate. Applicants at any stage of their graduate program may apply, as long as they will be available to accept two summers of paid internship. Those who already possess a doctoral degree are ineligible.

Type: Fellowship

Value: US\$27,000 annually, of which US\$20,000 is the fellow's expense allowance and US\$7,000 is GFSD's fee to support its operations. The charge is subject to change at the discretion of the GFSD Board of Directors.

Length of Study: Initial support may be for two or three years, or for a full six years, depending on the employersponsor.

Frequency: Annual

Country of Study: United States of America

No. of awards offered: Varies yearly

Closing Date: December

Additional Information: Applicants must be accepted at a participating GFSD-member university or college and progress through a full-time study program leading to a graduate degree in the physical sciences or related engineering fields. Fellows must complete one or two summer internships, as the sponsoring employer requires. To continue in good standing, fellows must submit a transcript annually as well as any forms and information that GFSD requests. Fellows must perform satisfactorily in their summer internship and during the academic year. A fellow who switches his or her field of study to one not of interest to the sponsoring employer will likely have support terminated. stemfellowships.org/fellows/

\section{Greater Kansas City Community Foundation}

1055 Broadway Blvd \#130, Kansas City, MO 64105, United States of America.

Website: www.growyourgiving.org

\section{Ann Maly Davis Scholarship Fund}

Purpose: The purpose of the Fund is to provide a one year scholarship to a two or four-year college or university for students graduating from Wahoo High School in Wahoo, Nebraska, or Royse City High School in Royse City, Texas, 
with a preferred emphasis on students intending to major in Business. This scholarship is also open to students attending college in Texas or Nebraska that meet the below criteria.

Eligibility: 1. Must attend Wahoo High School in Wahoo, Nebraska. 2. Must be a graduating high school senior. 3. Must have a grade point average of 3.0 or higher. 4 . This award is for United States of America students

Level of Study: Graduate

Type: Scholarship

Value: US $\$ 500$

Frequency: Annual

Country of Study: United States of America

Closing Date: 3 April

Funding: Foundation

Additional Information: gkccf.academicworks.com/oppor tunities/3061

\section{For further information contact:}

Tel: $\quad$ (1) 8166273436

Email: scholarships@growyourgiving.org

\section{Cheryl Barnett McLaughlin Wildcat Education Scholarship Fund}

Eligibility: 1. Must be a graduating high school senior or undergraduate student at the time of application. 2. Must be a high school senior or previous graduate in the Shawnee Mission School District. 3. Must be enrolled at or planning to enroll at Kansas State University. 4. Must be majoring in education. 5. This award is for United States of America students

Level of Study: Graduate

Type: Scholarship

Value: US $\$ 500$

Frequency: Annual

Country of Study: United States of America

Application Procedure: Application instructions and additional information about the CBM Wildcat Education Scholarship Fund are available online at the Greater Kansas City Community Foundation (GKCCF) website. In addition to the completed online application form, applicants for this scholarship must submit the following: proof of financial need; transcripts or other records of academic performance that include a current or recent grade point average; and additional information about any leadership roles, community service, or volunteer efforts that may be pertinent to the award. Completed applications with all supporting documents must be received no later than the deadline date. Late and incomplete submissions will not be considered

Closing Date: 15 April

Funding: Foundation
Additional Information: www.growyourgiving.org/scholar ships/cbm-wildcat-education-scholarship-fund

\section{For further information contact:}

Email: scholarships@growyourgiving.org

\section{Sam and Rosalee Scholarship Fund}

Purpose: The purpose of the Fund shall be to provide scholarships to graduates of high schools in Bates County, Missouri, who plan to further their education at a four-year college or university and pursue a degree in either the educational field or medical field

Eligibility: The students eligible for assistance shall, 1. be graduating from a high school in Bates County, Missouri. 2. have at least a 3.0 cumulative high school GPA. 3. demonstrate financial need; and 4 . be enrolling in a four-year college or university to pursue a degree in either the educational or medical fields

Level of Study: Graduate

Type: Scholarship

Frequency: Annual

Country of Study: Any country

Application Procedure: This award is managed and administered through the Greater Kansas City Community Foundation, a local area charity founded in 1978 with the mission of providing assistance and centralized resources for decentralized charitable causes and giving

Closing Date: 1 April

Funding: Private

Additional Information: For further information,www. growyourgiving.org/sites/default/files/scholarships/applica tion.pdf www.growyourgiving.org/scholarships/sam-androsalee-scholarship-fund

\section{For further information contact:}

Email: scholarships@growyourgiving.org

\section{Starke-Blosser Memorial Scholarship Fund}

Purpose: The Starke-Blosser Memorial Scholarship Fund is provided annually for graduating seniors at Higginsville High School, as well as undergraduate students who reside in Higginsville, Missouri

Eligibility: Applicants must demonstrate academic achievement, financial need, and participation in the community through service and other organizational involvement. Relatives of the Starke-Blosser family are also eligible to apply Level of Study: Graduate Type: Scholarship 
Value: US \$1,000 Funds may be used for tuition, books, and other educational fees

Frequency: Annual

Country of Study: Any country

Application Procedure: Students must submit the completed application form, as well as the following supporting documents: two letters of recommendation as described in the application; a short personal statement; and verification of enrollment in or acceptance to an accredited college or university. Any late or incomplete submissions will not be considered

Closing Date: 1 April

Funding: Private

Additional Information: www.growyourgiving.org/scholar ships/starke-blosser-memorial-scholarship-fund

\section{For further information contact:}

Tel: $\quad$ (1) 8166273436

Email: scholarships@growyourgiving.org

\section{Greek Ministry of National Education and Religious Affairs}

Greek Ministry of Education and Religious Affairs, Cultural and Sport, Directorate of International Relations in Education, GR-15180 Maroussi, Greece.

Tel: $\quad$ (30) 2103442469,2103443129

Email: des-a@minedu.gov.gr

Website: www.minedu.gov.gr

Contact: Directorate General of European and

International Affairs

The Ministry's department of scholarships grants exclusively scholarships to students and $\mathrm{PhD}$ holders from developing countries through the OECD's D.A.C.

\section{Scholarships for a Summer Seminar in Greek Language and Culture}

Purpose: To allow nationals from the Balkans, Eastern Europe, Asia and Africa to study Greek language

Eligibility: Applicants must be nationals of Albania, Armenia, Azerbaijan, Bosnia \& Herzegovina, China, Egypt, Ethiopia, FYROM, Georgia, India, Indonesia, Iran, Iraq, Jordan, Kazakhstan, Korea, Lebanon, Moldove, Montenegro, Mongolia, Pakistan, Palestine, Russia, Serbia, Sudan, Syria, Thailand, Tunisia, Turkey, Ukraine, or Uzbekistan.
Applicants should be foreign students/foreign professors of, Greek languages, or even foreign students/foreign professors of different fields who wish to improve their level of Greek language

Type: Scholarship

Value: The scholarships covers: accomodation, meals, tuition fees, small personal expenses, in case of an emergency medical care, visits to archaeological sites, museums, as well as instructive material

Frequency: Dependent on funds available

Country of Study: Greece

Funding: Government

\section{For further information contact:}

Email: foreigners@iky.gr

\section{Scholarships Granted by the GR Government to Foreign Citizens}

Purpose: To support candidates who wish to study or conduct research project in Greek Universities, or summer seminars of Greek language and culture, postgraduate studies

Eligibility: Applicants must be nationals of China, Belgium, Bulgary France, Germany, Serbia, Syria, Turkey. Applicants should have an excellent knowledge of Greek or French or English language. Applicant must be of foreign nationality of Estonia, Israel, Croatia, Cyprus, Luxembourg, Mexico, Norway, Netherlands, Hungary, Poland, Romania, Slovakia, Slovenia, Czech Republic, and Finland

Level of Study: Doctorate, Graduate, MBA, Postdoctorate, Postgraduate, Predoctorate, Research

Type: Scholarship

Value: $€ 550$ per month, $€ 500$ lump sum for establishment expenses, $€ 150$ for transport expenses, exemption from tuition fees (only in selected master's degree) plus all expenses for summer seminars except travel expenses

Length of Study: Varies

Frequency: Annual

Study Establishment: Greek public universities

Country of Study: Greece

Application Procedure: Check with Ministry of Education or Ministry of Foreign Affairs in Individual country. Applicants must apply through their home countries. Find out about deadlines of their own countries but also refer to the website No. of awards offered: 60

Closing Date: 31 March

Funding: Government

Contributor: Greek Ministry of Education and Religious Affairs, Culture and Sport

No. of awards given last year: 40

No. of applicants last year: 60 
Additional Information: Information about eligible countries, number of scholarships and the way to apply is renewed every year and candidates can find next year's decision by the end of December at www.minedu.gov.gr

\section{For further information contact:}

Directorate of Studies and Student's Welfare, Greece.

Tel: $\quad$ (30) 2103443469,2103443451

Email: foitmer.yp@minedu.gov.gr

\section{Greek Scholarships}

\section{Atlantic Amateur Hockey Association Lou Manzione Scholarship}

Purpose: The Atlantic Amateur Hockey Association is pleased to offer a scholarship program to students who plan to continue their education beyond the 12th grade. Scholarships are available, one to a New Jersey High School Senior and the second to a high school senior from Pennsylvania or Delaware

Eligibility: 1. The applicant must be pursuing education after the 12th grade. 2 . The applicant should be a New Jersey High School Senior. 3. The applicant should be a high school senior from Pennsylvania or Delaware. 4. The applicant must be registered with USA Hockey.

Level of Study: Graduate

Type: Scholarship

Value: US\$1,000

Frequency: Annual

Country of Study: United States of America

Application Procedure: 1. To be considered for this scholarship award, a candidate must complete a scholarship application form. 2. A candidate is required to submit an academic transcript from the previous semester. 3 . He/she also needs to submit the ACT/SAT score report to determine academic achievement. 4. A student must provide a list of any participated High School Activities \& Awards, List any awards or other forms of recognition that he/she has received. 5. A recipient must provide a letter of recommendation from the school's principal or guidance counselor, 6 . Additionally, an applicant must write an essay that must give details about an applicant's background, interests, and future plans.

No. of awards offered: 2

Closing Date: 2 January

Funding: Private

Additional Information: www.thecollegemonk.com/scholar ships/aaha-lou-manzione-scholarship

\section{For further information contact:}

Scholarship Committee, P.O. Box 213, Lafayette Hill, PA 19444, United States of America.

Email: info@aahahockey.org

\section{Cancer for College Carolinas Scholarship}

Purpose: The Cancer for College Carolinas Scholarship is open to any cancer survivor who is enrolled in an accredited college or university in the United States

Eligibility: 1. The applicant must be a U.S. resident. 2. The applicant must be enrolled as a full-time student at an accredited institution. 3. The applicant must be from a state of North or South Carolina school.

Level of Study: Graduate

Type: Scholarship

Value: US $\$ 5,000$

Frequency: Annual

Country of Study: Any country

Application Procedure: 1. The students applying for this grant must submit a Free Application for Federal Student Aid (FAFSA) application. 2. The initial two pages of the proper 2019 assessment form, If a candidate is under 25 and professing to be autonomous, should give your parent's profits to show that they don't guarantee you. 3. Two-years of Academic Transcripts (High School, College or Combination depending on your year in school), 4. Two Letters of Recommendation from two individuals OUTSIDE your family must be submitted by the candidates.

Closing Date: 31 January

Funding: Private

Additional Information: www.scholarships.com/financialaid/college-scholarships/scholarships-by-type/cancer-scholar ships/cancer-for-college-carolinas-scholarship/

\section{For further information contact:}

28465 Old Town Front Street, Suite 315, Temecula, CA 92590, United States of America.

\section{Tel: $\quad$ (1) 7605995096}

Email: applications@cancerforcollege.org

\section{Candice Sickle Cell Disease Scholarship}

Purpose: Our goal is to help alleviate the financial pressures of college-bound students in the Tri-State Area (NY/NJ/CT) with sickle cell disease by providing three scholarships annually. These scholarships are awarded to assist scholarship recipients with their college education 
Eligibility: Every scholarship winner is required to commit at least 5 hours minimum of their time towards one of the various Candice's Sickle Cell Fund activities during the year they receive their scholarship

Level of Study: Graduate

Type: Scholarship

Value: US\$750-US\$1,500

Frequency: Annual

Country of Study: Any country

Application Procedure: 1. Each applicant must submit a 250-word essay typewritten in double-spaced format to include how sickle cell disease has affected their life and education. 2. Each applicant should also include what their educational goals are and how they expect to achieve them, in addition, what person has been instrumental in their lives to help them persevere

Closing Date: 15 February

Funding: Private

Additional Information: www.washington.edu/doit/ candices-sickle-cell-disease-scholarship

\section{For further information contact:}

Candice Young-Deler, P.O. Box 672237, Bronx, NY $10467-$ 0237, United States of America.

Tel: $\quad$ (1) 6464360477

Email: cscfinc@gmail.com

\section{Dixie Youth Baseball Scholarship}

Purpose: Scholarships are presented annually to deserving high school seniors who participated in the Dixie Youth Baseball program while age 12 and under.

Eligibility: 1. Must be an undergraduate student 2. Must attend a university, a four-year college, two-year college or a vocational-tech school 3. Citizenship requirements: US 4. Must currently be a high school student 5. Must study full-time 6. Restricted to residents of Alabama, Arkansas, Florida, Georgia, Louisiana, Mississippi, North Carolina, South Carolina, Tennessee, Texas, Virginia

Level of Study: Graduate

Type: Scholarship

Value: US\$2,000

Frequency: Annual

Country of Study: Any country

No. of awards offered: 60

Closing Date: 1 February

Funding: Private

\section{For further information contact:}

PO Box 877, Marshall, TX 75671-0877, United States of America.

Tel: $\quad$ (1) 9039272255

Email: dyb@dixie.org

\section{Eileen Kraus Scholarship}

Purpose: Mrs. Kraus is a past Chairman of the Board and currently a Trustee Emerita. She also served on the Board of Directors of Kaman Corporation for more than 20 years. This scholarship honours her achievement

Eligibility: Eligible applicants must be 1. Female students currently residing in Connecticut. 2. Recent high school graduates or in the final year of secondary school. 3. Intending to enroll in first year of college or university. 4. Able to attend the Connecticut Women's Hall of Fame Induction Ceremony in Hartford, CT for recognition

Level of Study: Graduate

Type: Scholarship

Value: US\$5,000

Length of Study: 2 to 4 years

Frequency: Annual

Country of Study: Any country

Closing Date: 15 February

Funding: Private

Additional Information: www.petersons.com/scholarship/ eileen-kraus-scholarship-111_216040.aspx

\section{For further information contact:}

Connecticut Women's Hall of Fame, 320 Fitch Street, B-3, New Haven, CT 06515, United States of America.

Tel: $\quad$ (1) 2033929008

Email: scholarships@cwhf.org

\section{Environmental Professionals' Organization of Connecticut Environmental Scholarship Fund}

Purpose: The purpose of the Scholarship Fund is to assist Connecticut residents, or an immediate family member (spouse or child) of an EPOC Member in good standing, who are attending an accredited college or university

Eligibility: Kindly contact sjm@epoc.org for further information

Level of Study: Graduate

Type: Funding support

Frequency: Annual

Country of Study: Any country 
Closing Date: 30 April

Funding: Private

Additional Information: For further information about the EPOC Scholarship Fund, contact Seth Molofsky at (860) 537-0337 or Email:epoc@epoc.org www.epoc.org/ epoc-news/7000206

\section{For further information contact:}

P.O. Box 176, Amston, CT 06231-0176, United States of America.

Tel:

(1) 8605370337

Fax: (1) 8606032075

Email: epoc@epoc.org

\section{Islamic Scholarship Fund - Muslim Community Center Scholarship}

Purpose: Islamic Scholarship fund supports Islamic organizations and mosques by planning and managing joint scholarships. ISF is honored to host the ISF-MCC Scholarship of the Muslim Community Center East Bay, MCC

Eligibility: Each Eligible Applicant Must Be: 1. An active member of the MCC. 2. Attending an accredited university in the United States of America. 3. Majoring in an ISF supported field of study. 4. Maintaining a minimum 3.0 Grade Point Average. 5. A Citizen or Permanent Resident of the United States of America. 6. An undergraduate (sophomore/junior/ senior) or of graduate standing

Level of Study: Graduate

Type: Scholarship

Value: US $\$ 5,000$

Frequency: Annual

Country of Study: Any country

Closing Date: 21 March

Funding: Private

Additional Information: islamicscholarshipfund.org/isfmec-scholarship/

\section{For further information contact:}

Islamic Scholarship Fund, P.O. Box 802, Alamo, CA 94507, United States of America.

\section{Tel: $\quad$ (1) 6509956782}

Email: contact@islamicscholarshipfund.org

\section{Oregon-Idaho Conference Ethnic Leadership Award}

Purpose: The Oregon-Idaho Conference Ethnic Leadership Award is for one undergraduate or graduate, ethnic student who is a member of an Oregon-Idaho Conference church

Level of Study: Graduate, Undergraduate

Type: Award

Value: US\$750 - US\$800

Frequency: Annual

Country of Study: Other

Application Procedure: Applicants are evaluated primarily on their leadership or potential leadership skills. Financial need is also considered. The scholarship may be used at any two- or four-year accredited institution of higher education

Closing Date: 1 March

Funding: Private

Additional Information: www.umoi.org/scholarships

\section{For further information contact:}

Scholarship Committee, P.O. Box 340007, Nashville, TN 37203-0007, United States of America.

Email:1inda@umoi.org

\section{Teacher Education Assistance for College and Higher Education Grant}

Purpose: You'll be able to teach in public or private elementary and secondary schools, as long as you sign on to teach in low-income areas in high-need fields. As a federal grant, you'll need to fill out a Free Application for Federal Student Aid, or FAFSA, to determine whether you're eligible for the TEACH Grant

Eligibility: 1. demonstrate financial need (for most programs). 2. be a United States of America citizen or an eligible noncitizen have a valid Social Security number (with the exception of students from the Republic of the Marshall Islands, Federated States of Micronesia, or the Republic of Palau). 3. be registered with Selective Service, if you're a male (you must register between the ages of 18 and 25). 4. be enrolled or accepted for enrollment as a regular student in an eligible degree or certificate program. 5 . be enrolled at least half-time to be eligible for Direct Loan Program funds Level of Study: Graduate

Type: Programme grant

Value: US $\$ 4,000$ per year

Frequency: Annual

Country of Study: Any country

Closing Date: October

Funding: Private 
Additional Information: studentaid.gov/understand-aid/ types/grants/teach

For further information contact:

Tel:

(1) 8005577394

Email: HEAL@ed.gov

\section{Griffith University}

Griffith University, Nathan Campus, 170 Kessels Road, Nathan, QLD 4111, Australia.

Tel:

$$
\text { (61) } 737353870
$$

Email:_scholarships@griffith.edu.au

Website: www.gu.edu.au

In the pursuit of excellence in teaching, research and community service, Griffith University is committed to innovation, bringing disciplines together, internationalization, equity and social justice and lifelong learning, for the enrichment of Queensland, Australia and the international community.

\section{Griffith Remarkable Scholarship}

Eligibility: 1 . Be a citizen of a country other than Australia or New Zealand. 2. Have a minimum GPA in previous studies of 5.5 or above on a 7 point scale or equivalent. Check your suitability in the Minimum GPA criteria (PDF). 3. Have applied to study at Griffith by the scholarship application closing date. 4. Satisfy all academic and English language entry requirements for your chosen undergraduate or postgraduate coursework program. 5. Be a full-time student starting in Trimester 1, 2 or 32021.

Level of Study: Postgraduate

Value: $50 \%$ of tuition fees

Frequency: Annual

Country of Study: Any country

Closing Date: 6 August

\section{International Student Academic Excellence Scholarship}

Eligibility: 1 . Be a citizen of a country other than Australia or New Zealand. 2. Have a minimum GPA in previous studies of 5.5 or above on a 7 point scale or equivalent. Check your suitability in the Minimum GPA criteria (PDF). 3. Satisfy all academic and English language entry requirements for your chosen undergraduate or postgraduate coursework program. 4. Be a full-time student starting in either Trimester 32020 , or Trimester 1, 2 or 32021.

Level of Study: Postgraduate

Type: Scholarship

Value: $25 \%$ of tuition fees

Frequency: Annual

Country of Study: Any country

\section{International Student Academic Merit Scholarship}

Eligibility: 1 . Be a citizen of a country other than Australia or New Zealand. 2. Have a minimum GPA in previous studies of 5.0 to 5.49 on a 7 point scale or equivalent. Check your suitability in the Minimum GPA criteria (PDF). 3. Satisfy all academic and English language entry requirements for your chosen undergraduate or postgraduate coursework program. 4. Be a full-time student starting in either Trimester 32020 , or Trimester 1, 2 or 32021.

Level of Study: Postgraduate

Type: Scholarship

Value: $20 \%$ of tuition fees

Frequency: Annual

Country of Study: Any country

\section{Master of Business Administration Programme}

Length of Study: $1-3$ years

Country of Study: Any country

Application Procedure: Applicants must complete an application form supplying Australian AU\$50 fee, official transcripts, and TOEFL score

For further information contact:

Tel: $\quad$ (61) 738757111

Fax: (61) 738753900

Email: gsm_enquiry@gsm.gu.edu.au

\section{PhD Scholarship in Water Resources Management in Remote Indigenous Communities}

Purpose: To utilize smart meters and loggers to gauge the degree of water savings attributable to the execution of various water conservation strategies

Eligibility: Open only to the citizens of Australia or New Zealand or permanent residents who have achieved Honours 1 or equivalent, Honours $2 \mathrm{a}$ or equivalent, or Masters or equivalent

Level of Study: Graduate, Postgraduate

Type: Scholarship 
Value: The scholarship has an annual tax-free stipend of AU \$30,000-35,000 per year

Frequency: Annual

Study Establishment: Griffith University

Country of Study: Australia

Application Procedure: Applicants must apply directly to the scholarship provider. Check the website for further details

Closing Date: 23 October

\section{For further information contact:}

Tel: (61) 737356596

Email: M.Mitchell@griffith.edu.au

\section{Gypsy Lore Society}

5607 Greenleaf Road, Cheverly, MD 20785, United States of America.

Tel: $\quad$ (1) 3013411261

Email: headquarters@gypsyloresociety.org

Website: www.gypsyloresociety.org

Contact: Ms Sheila Salo, Treasurer

The Gypsy Lore Society, an international association of persons interested in Gypsy Studies, was formed in the United Kingdom in 1888. The Gypsy Lore Society, North American Chapter, was founded in 1977 in the United States of America and since 1989, has continued as the Gypsy Lore Society. The Society's goals include the promotion of the study of the Gypsy peoples and analogous itinerant or nomadic groups, dissemination of information aimed at increasing understanding of Gypsy culture in its diverse forms and establishment of closer contacts among Gypsy scholars.

\section{Marian Madison Gypsy Lore Society Young Scholar's Prize}

Purpose: To recognize outstanding work by young scholars in Romani (Gypsy) studies

Eligibility: Graduate students beyond the 1st year of study and $\mathrm{PhD}$ holders no more than 3 years beyond the degree. An unpublished paper not under consideration for publication is eligible for this award as well as self-contained scholarly articles of publishable quality that treat a relevant topic in an interesting and insightful way

Level of Study: Doctorate, Graduate, Postdoctorate

Type: Cash prize

Value: US\$500

Study Establishment: Any

Country of Study: Any country

Application Procedure: Submission file format is rich text file (RTF, PDF, MS word compatible). Files bigger than $5 \mathrm{MB}$ should be presented on $\mathrm{CD}$ to the postal address below. A cover sheet should be included with the title of the paper, the author's name, affiliation, mailing, email address, telephone and fax number, date of entrance into an appropriate program or of awarding of the $\mathrm{PhD}$, and United States of America social security number, if the author has one. The applicant's name should appear on the cover sheet only

Closing Date: 15 January

Funding: Corporation

Contributor: Gypsy Lore Society

Additional Information: www.gypsyloresociety.org/gypsy-

lore-society-young-scholars-prize

\section{For further information contact:}

Email: szahova@yahoo.com 